\title{
個別要素法を用いた 大規模土砂流動実験の再現解析
}

\author{
森口＼cjkstart周二 1 -太田 勇真 2 ・高瀬 慎介 3 ・寺田 賢二郎4 ・ \\ 阿部 慶太 5 ・青木 尊之 6 \\ 1博（工）東北大学准教授災害科学国際研究所（９980- 0845 仙台市青葉区荒巻字青葉468-1） \\ E-mail: s_mori@irides.tohoku.ac.jp \\ 2日揮株式会社（テ220-6001 横浜市西区みなとみらい2-3-1） \\ 3 博（工）東北大学助教大学院工学研究科（ $\bar{T} 980-0845$ 仙台市青葉区荒巻字青葉468-1） \\ ${ }^{4} \mathrm{Ph} . \mathrm{D}$ 東北大学教授 災害科学国際研究所（干980-0845 仙台市青葉区荒巻字青葉468-1） \\ 5 博（工） 公益財団法人鉄道総合技術研究所（广185-8540 東京都国分寺市光町二丁目8番地38） \\ 6博（理）東京工業大学学術国際情報センター（†152-8550 東京都目黒区大岡山2-12-1）
}

\begin{abstract}
個別要素法を用いて土砂の衝撃力を評価をする上で重要となる計算条件の整理を目的として，大規模土 砂流動実験の再現解析を実施した。特に，要素サイズや要素形状を変化させることで，これらの要因が解 析結果に及ぼす影響について調べた。その結果, 要素サイズの重要性や, 球形要素と非球形要素の特性な どが明らかとなった。 また，得られた知見に基づいて個別要素法を衝撃力評価に用いる際の評価フローを 提案し, 工学的な観点から留意点などについて整理した。
\end{abstract}

Key Words : DEM, large scale experiment, impact force

\section{1. 序論}

流動土砂の危険度評価（主に到達距離と衝撃力）につ いては, これまでに多くの研究がなされており，それら を評価するための実験的検討1-3)，データに基づく統計解 析 ${ }^{40)}$, 数值解析》) など、古くから様々な研究が展開され ている．また，実務レベルでは，2001年の国土交通省告 示第三百三十二号において, 土砂の衝撃力の算定式8)

（以下，従来手法と記す）が具体的に示されている. し かしながら，現状の簡易的な評価手法では，失点系の考 え方に基づいて斜面の平均勾配を用いた評価となってお り, 斜面上での土砂の流動速度の時間的変化や斜面勾配 が変化する場合の評価が難しく, 到達距離や衝撃力の3 次元的な分布などの情報も直接的には得ることができな い. このような課題を克服する手段として，実務レベル における数值解析の利用促進は重要な課題である.

数值解析については, 主に深さ方向に圧力や速度の分 布に関する仮定を含む支配方程式を用いて，平面方向の 運動を解く手法110が古くから研究されているが，近年 では, 計算機能力の発展に伴って深さ方向に仮定を用い ずに直接的に現象を表現する手法も数多く報告されてい

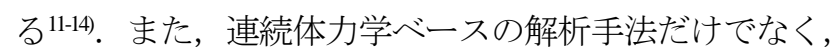
離散体モデルも活用されており, 個別要素法（DEM :
Discrete Element Method） ${ }^{15)}$ や不連続変形法（DDA： Discontinuous deformation analysis） 1 の などの手法を代表とし て今後の利用拡大が期待されている. 特に, DEMにつ いては数多くの適用例17-20)が報告されている，ただし， DEMは斜面や粒子の形状を直接的に表現できるという 利点を有する一方で，工学的な利用に対して必要となる 計算条件などに関しては十分に議論されているとは言い 難い，実務レベルでのDEMの利用価值を高めるために は, 工学的に意味のある結果を得るために最低限必要と なる計算条件や評価の手順などを整備しておく必要があ る.このような現状を背景として，本研究では，DEM を土砂の衝撃力評価に適用する上で留意すべき工学的条 件を整理することを目的として，大規模土砂流動実験の 再現解析を実施した.

\section{2. 実大規模土砂流動実験}

本研究で再現解析の対象とした実大規模実験31は，図 -1 に示寸実験施設で実施されたものである. 本実験で は，土砂流動実験だけでなく，落石に関する実験も実施 されているが，本研究では土砂流動に関する実験のみを 対象とする．また，体積の異なる実験ケースが存在する が，本研究においては，全体の体積が $1.0 \mathrm{~m}^{3}$ の砕石（粒 
度調整砕石）を流動させたケースを対象とする．図ー1 に示すように，斜面は幅 $5.0 \mathrm{~m}$ ，長さ $5.0 \mathrm{~m}$ の $43^{\circ}$ 勾配斜面， 長さ $5.77 \mathrm{~m}$ の $29^{\circ}$ 勾配斜面, および長さ $7.5 \mathrm{~m}$ の平坦部か らなり，底面構造は，盛土表面にコンクリート吹付け工 を行い，その上にPC 板を複数枚敷設している. 斜面下 には，荷重計を内蔵した反力壁が設置されており，この 装置により土砂の衝撃力を計測している. 反力壁は，図 一2に示すように, 容量 $20 \mathrm{kN}$ の荷重計1つに対して受け 面 $0.5 \mathrm{~m} \times 0.5 \mathrm{~m}$ があり，これを 4 並列 $(0.5 \mathrm{~m} \times 2 \mathrm{~m})$ に並心゙ たものである．砕石は，斜面上部のトラックの荷台に所 定の体積となるように投入され，図一3に示すように荷 台を斜面流下方向に向けて傾けていくことで流動を発生 させている. 実験で用いられた砕石の写真を図ー4に示 す．また，トラックの荷台に投入された状態の砕石の体 積と密度, および土粒子密度を表一1に示す。

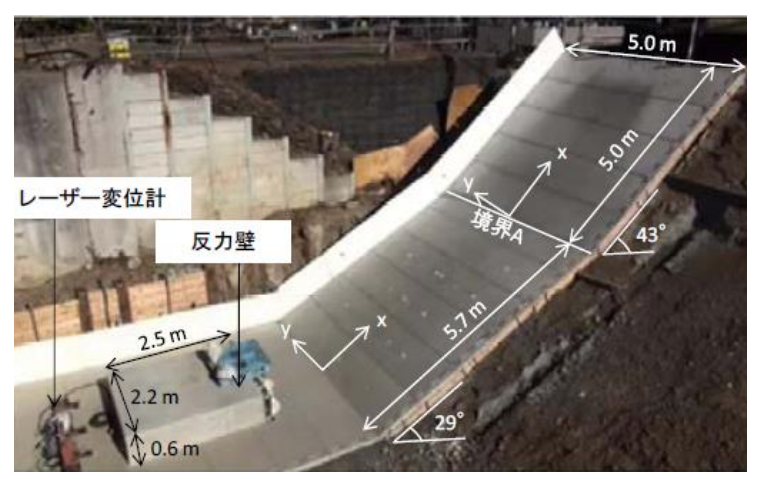

図-1 実験施設 3$)$

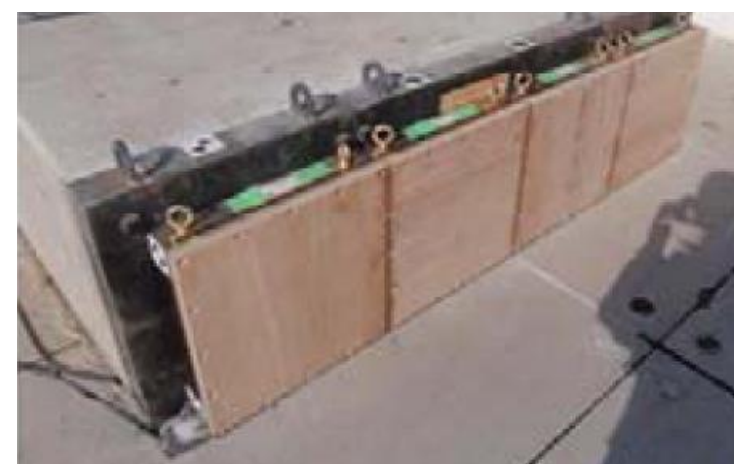

図-2 反力壁

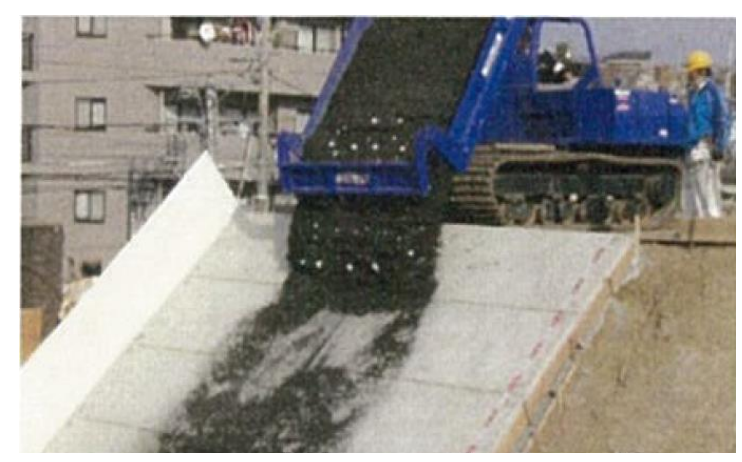

図－3 流動発生時の様子

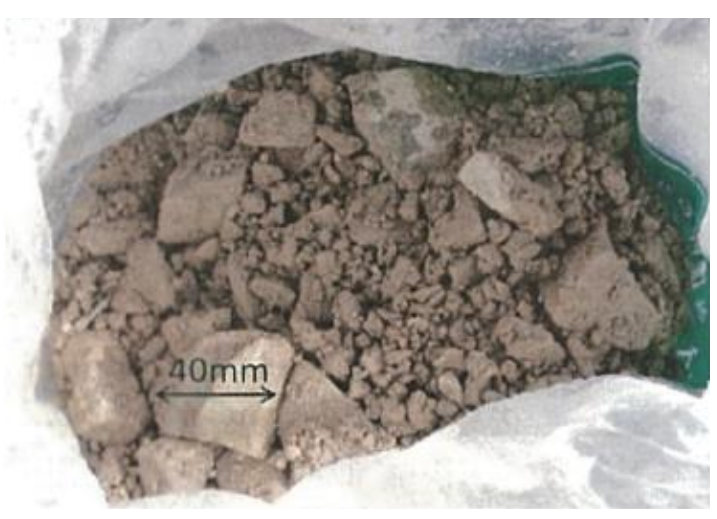

図－4 実験に用いられた粒度調整砕石

\begin{tabular}{lc} 
表 -1 実験に用いられた粒度調整砕石の情報 \\
\hline 体積 $\left(\mathrm{m}^{3}\right)$ & 1.0 \\
\hline 密度 $\left(\mathrm{kg} / \mathrm{m}^{3}\right)$ & 1850 \\
\hline 土粒子密度 $\left(\mathrm{kg} / \mathrm{m}^{3}\right)$ & 2724 \\
\hline
\end{tabular}

\section{3. 実験の再現解析}

\section{（1）解析手法}

本研究では，DEM用いて先述の大規模土砂流動実験 を再現する。本研究で用いたDEMは，球要素，三角形 要素, 面要素が扱えるものであり, 要素間力モデルは図 一5に示す一般的なものである. 法線方向と接線方向の それぞれにバネとダッシュポットがあり, 加えて接線方 向には摩擦力を制御するためのスライダーが存在する. なお，計算の効率化を目的として，ポリゴン要素の配置 からLevel set 関数21-22)を作成し，その情報に基づいて球要 素と面の接触を評価している. Level set 関数は，空間的 に離散化された計算点上で連続した面からの距離を表現 することが可能であり, 混相流解析や画像処理の分野で 広く用いられているが, 近年では, 固体間の接触問題に も適用されている23). なお，法線方向と接線方向のバネ とダッシュポットの係数は同じであると仮定し，ダッシ ユポットの粘性係数を直接入力值とするのではなく，振 動方程式との対応に基づいて反発係数を入力值としてエ ネルギー減衰をコントロールしている24).つまり，バネ 定数, 反発係数, 摩擦係数を入力值としている.

\section{(2) 解析条件}

先述のように, 本研究では解析条件を様々に変化させ て再現解析を実施することにより，DEM を用いた土砂 流動解析に対する解析条件の整理を目的とする. 要素サ イズについては，4,5,6,7,8,9,10cm の 7 種類とし, 粒子形 状については, 図一6に示す 3 種類の非球形モデル（球 形，直線形，テトラ形）を用いた. 本研究で設定した要 素サイズの最小值が $4 \mathrm{~cm}$ であるのに対して，実験に用 
いられた砕石は最大粒径が $4 \mathrm{~cm}$ 程度であり, 本研究で 設定した要素サイズは実際の砕石のサイズと比べて大き い. また，実際の砕石には細粒分も含まれているが，本 研究では単一粒径とし, 粒度分布の影響についても本研 究の検討対象外とした. この理由は, 本研究では実験そ のものを直接的に表現するのではなく，工学的利用を意 識して DEM を土砂の衝撃力評価に適用する上で留意す べき点を整理することを目的としているためであり，議 論が複雑になるのを避けるためにシンプルな解析条件を 設定している.

図一7 は解析に用いた斜面のモデルであり，ポリゴン 要素で斜面形状および反力壁を表現した. トラックの荷 台からの流下を表現するために，荷台と同じサイズの箱 型の領域内に DEM 要素を配置して初期状態を作成して いる. なお, 初期状態の要素配置は自由落下の条件で作 成しており，実験で用いられた質量と一致するように要 素数を調整している. 反力壁については，実験と同じく, 受け面 $(0.5 \mathrm{~m} \times 2 \mathrm{~m})$ を設定し，DEM 要素が受け面に接 触する際に発生する力を合計して時系列データとして取 得した.

本解析に用いた入力パラメータを表一2 に示寸. 実験 では, 砕石と斜面底面の静摩擦係数と動摩擦係数が計測 されており，動摩擦係数の值が 0.394 であったため，そ の值加換算して底面摩擦角を $22^{\circ}$ と設定している. なお，砕石同士の摩擦角については情報が存在しないた め, 一般的な值として $30^{\circ}$ と設定した. バネ定数と反 発係数についても, 実験のデータの中にこれらを直接的 に推定できる情報がないため, 同じ実験を対象とした先 行研究 3などを参考に值を設定し, パラメトリックスタ ディにより感度分析を行うことで值の妥当性を確認して いる. その結果については後述する.

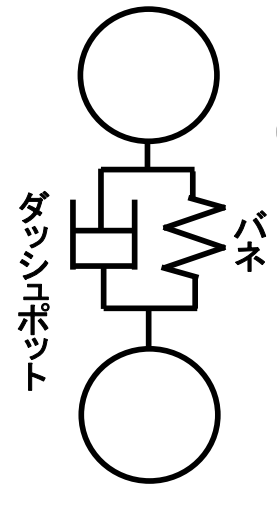

法線方向

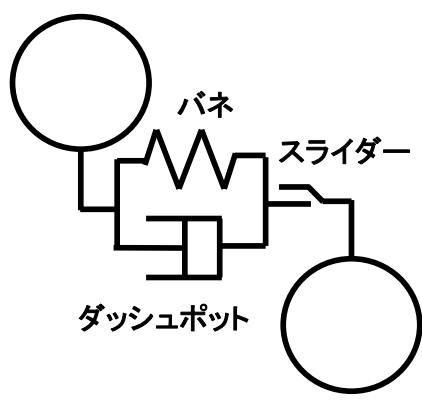

接線方向
図-5 要素間力モデル

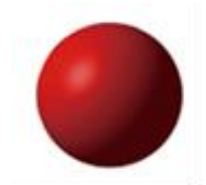

球形

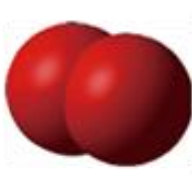

直線形

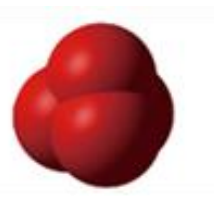

テトラ形
図一6 球形要素と非球形要素

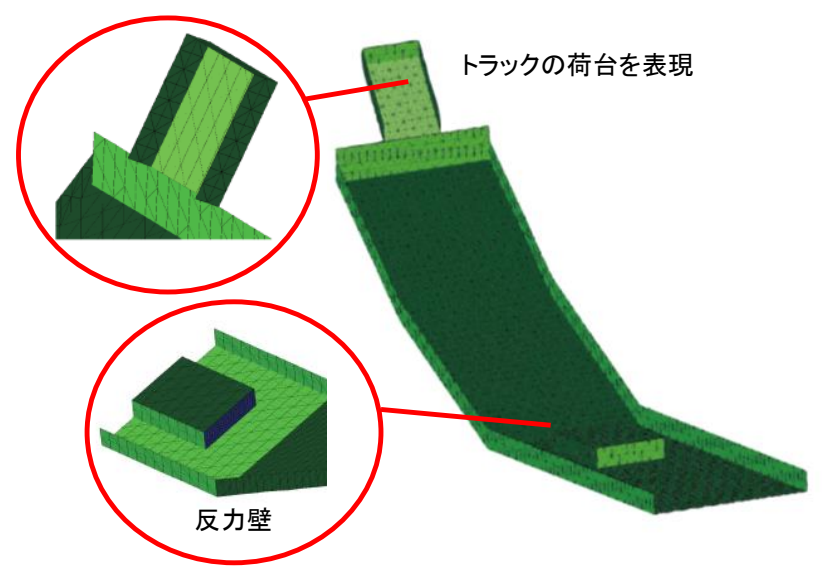

図一7 解析モデル（斜面）

表一2 解析パラメータ

\begin{tabular}{lc}
\hline 時間増分 $(\mathrm{sec})$ & $1.0 \times 10^{-6}$ \\
\hline バネ定数 $(\mathrm{N} / \mathrm{m})$ & $1.0 \times 10^{6}$ \\
\hline 反発係数 & 0.1 \\
\hline 底面摩擦角(度) & 22 \\
\hline 粒子間摩擦角(度) & 30 \\
\hline
\end{tabular}

\section{(3) バネ定数と反発係数の感度分析}

先述のように，解析パラメータの検証のため，バネ定 数と反発係数のパラメトリックスタディを行い, 感度を 分析した. なお, この解析には, 直径 $4 \mathrm{~cm}$ の球形要素 を用いた．図一8 と図一9 は，それぞれバネ定数と反発 係数を変化させて得られた衝撃力の時刻歴である. 衝撃 力の評価については, 先述のように図一7 の衝撃壁を構 成するポリゴンに衝突する DEM 要素に作用する力の合 計として表現している. まず，バネ定数については，表 -2 に示した值の $1 / 10$ と 10 倍の值を用いたが，バネ定 数の值が高いほど衝撃力のピーク值が大きくなる傾向は あるものの，それほど顕著な差ではないことが確認でき る. また, 反発係数についても, 工学的判断を加味して, 0.1 0.3 の範囲で変化させており, 反発係数が高いほど ピーク值が高くなる傾向はあるが，やはり衝撃力の時刻 歴としてはそれほど顕著な差になっていない.ここで, 時刻歴にそれほど顕著な差が現れない理由について言及 する. 1 つ物体の衝突を考えた場合，バネ定数は接触時 間を, 反発係数はエネルギー減衰の程度を支配し，接触 開始から離反までの力積に影響を与えるため, 衝撃力に も強い影響を与えることは容易に想像できる．これに対 し, 本研究で対象としているような粒状体の斜面上の流 動では，重力の作用による流下挙動が支配的であり，粒 子同士の接触における接触時間やエネルギ一減衰の程度 がそれほど顕著に減少に影響しないためと考えられる。 特に, ここで示したパラメトリックスタディの結果は, 
球要素を用いたものであるため，その傾向が強く出てい ると思われる. なお, 非球形要素の場合にはより複雑に 解析結果に影響すると思われるが，その議論を㛜密に行 うためには, より多くの非球形要素の形状や, 形状の度 合いまでを含めて検討する必要がある。そのため, 本研 究では同じパラメータを用いた場合の球形要素と非球形 要素の結果の違いを概略的に検討するという方針とし, 図-8 と図-9 に示した結果の中で大きな差が生じてい ないことを理由として，表一2 に示したパラメータの值 でも，検討が可能であると判断した.

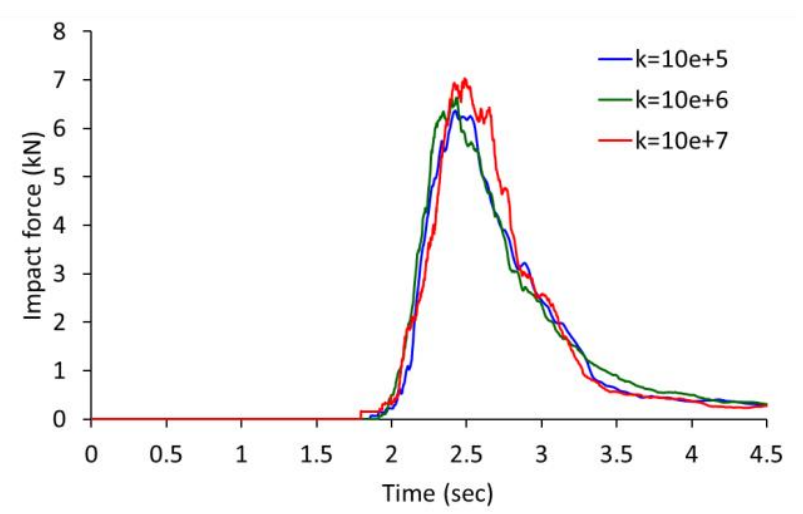

図-8 バネ定数の影響（球形要素 4cm）

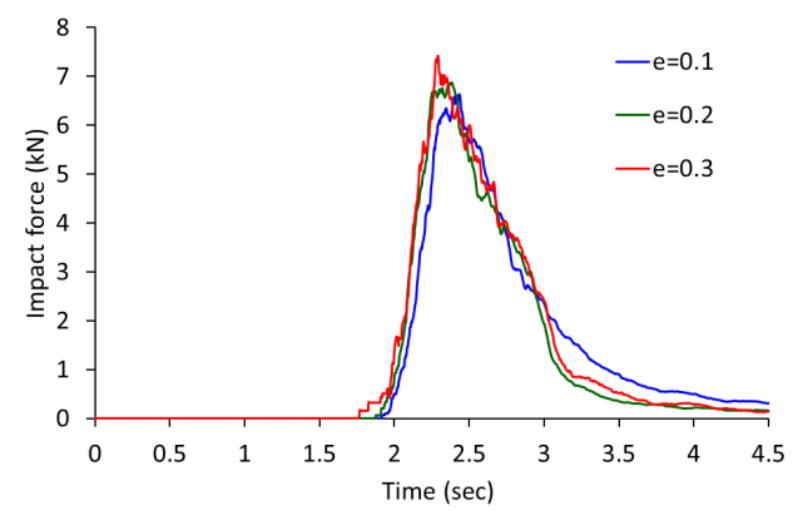

図一9 反発係数の影響（球形要素 4cm）

\section{(4) 再現解析の結果}

ここまでに示した解析条件および解析パラメータを用 いて，先述の実大規模実験の再現解析を実施した。まず, 得られた流動挙動について説明する. 図ー10に，実験で 撮影された砕石の流動の様子を示す. また，解析結果の 代表的な例として, 図-11に直径 $4 \mathrm{~cm} の$ 球形要素の結果 を，図-12に直径4cmの直線形要素の結果を示している. 球形要素については，実験結果に比べて流動速度が速く， 斜面下の平坦部で流動が止まらず，実験結果に見られる 砕石の堆積状況を表現できていないことが確認できる. この理由は，球形要素は容易に回転することができるた めに底面での摩擦が発生しにくく, 流動速度が低下しに くいためである.これに対して，直線形要素については， 実験結果に比べて流動速度が若干遅く, 斜面下の平坦部
に達した後に急激に速度が低下するため, 実験結果に比 ベて反力壁の手前で堆積していることが確認できる，テ トラ形要素についても概ね同じような傾向が確認されて いる.
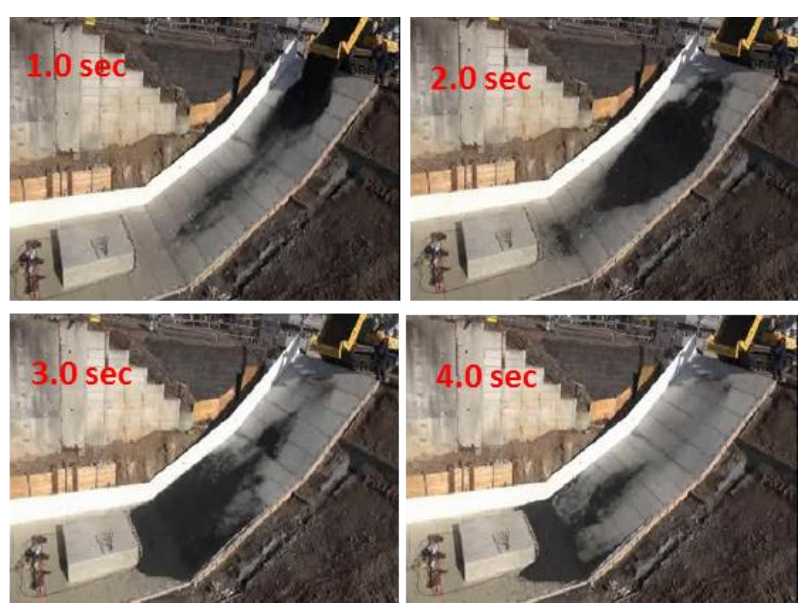

図-10 流動の様子（実験）

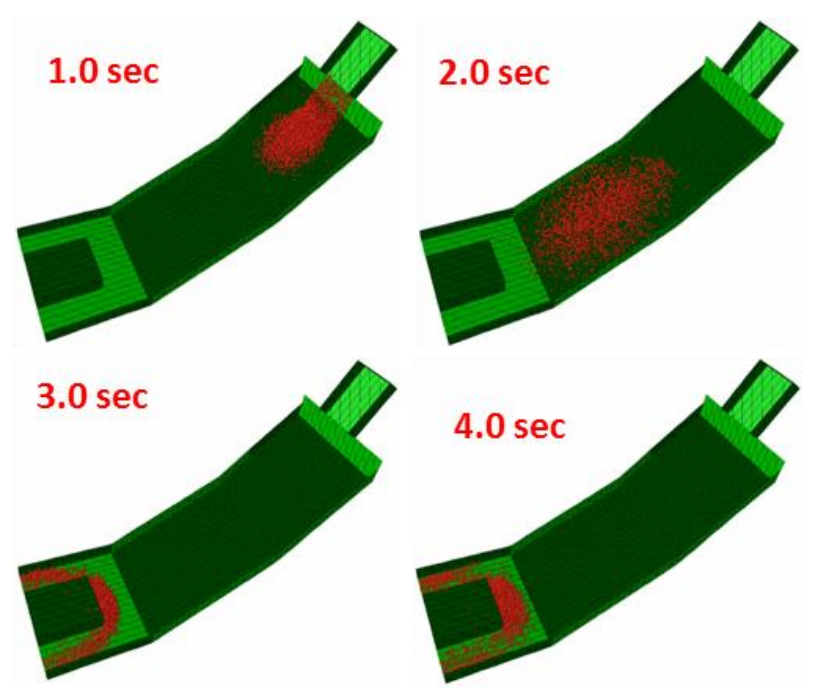

図-11 流動の様子（解析結果, 球形要素 4cm)
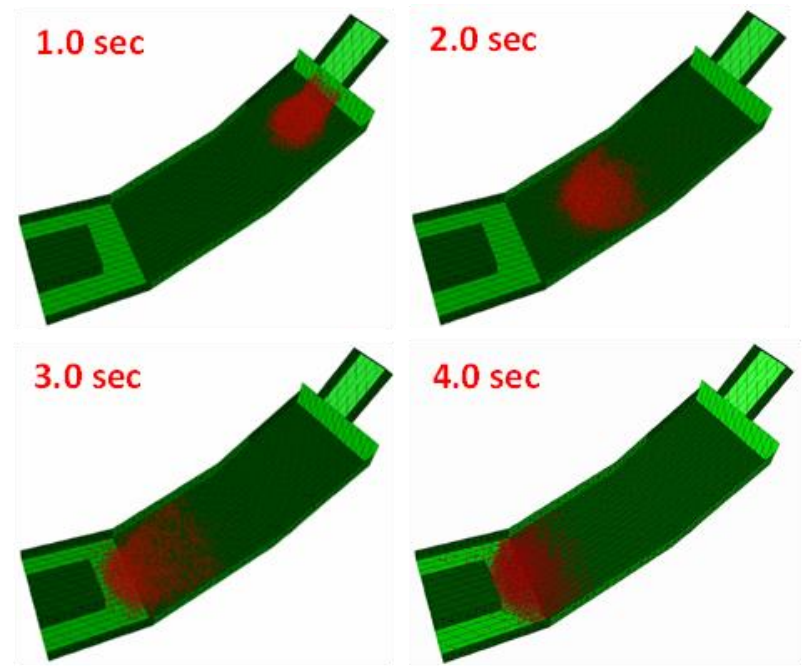

図-12 流動の様子（解析結果, 直線形要素 4cm) 
次に, 衝撃力について実験結果と解析結果を比較する. ここでは全ての解析ケースを対象として実験結果との比 較を行う。図一13,15,17 は，それぞれ球形要素，直線形 要素, テトラ形要素を用いた解析結果から得られた衝撃 力の時刻歴である. 解析の中で考慮した全ての要素サイ ズの結果を示している. なお，比較のために，実験で得 られた衝撃力の時刻歴も図中に示している. また, 図一 14,16,18 は最大衝撃力と要素サイズの関係として整理し たものである.これらの結果より，次のことが確認でき る.

まず，球形要素については，解析結果はどれも実験結 果に対して大きな衝撃力を示しており, 衝撃力が発生す る時刻も実験結果と比べて早い. この結果は, 図-11に 示した流動の傾向と整合する. また, 要素サイズが大き いほど大きな衝撃力が発生しており, さらに, 要素サイ ズが小さくなるにつれて衝撃力の時刻歴がある一定のラ インに収束していることが確認できる.このことは，図 -14 の最大衝撃力と要素サイズの関係の図でより明確に 確認できる. 要素サイズが大きい場合に衝撃力を過大評 価する理由は, 要素サイズが大きい場合は要素数が少な いため接触回数が減ること，および，個々の要素の体積

（または質量）に対する表面積の比が小さくなることか ら，全体としてエネルギ一損失が小さくなるためと考え られる. つまり, 要素サイスが大きい場合は, 土砂流動 というよりも複数の岩石が斜面上を転がっている現象に 近くなっていると考えられる. そのため, 少なくとも対 象としている土砂流動という現象から外孔ない程度のモ デル化を行うという意味で, 衝撃力が一定の值になるよ うな条件（要素サイズに依存しない解を得ることができ る条件）で解析を実施する必要があり，衝撃力が収束す る条件の要素サイズを把握するための検討は, 土砂流動 による衝撃力評価の中で極めて重要なプロセスと考えら れる.

次に, 直線形要素とテトラ形要素の結果について分析 する. 球形要素の傾向と同じく要素サイズを小さくする に伴って, 衝撃力の最大值や時刻歴が収束していること が確認できる.ただし, 球形要素とは逆に, 実駼結果に 対して衝撃力を過小評価している.この結果も図-12に 示した流動の様子と整合する. また, 直線形要素とテト ラ形要素の結果で, 衝撃力の值に若干差が生じているこ とが確認できる．このことが意味するのは，同じ非球形 要素でも, 形状によって流動挙動や衝撃力に差が生じる ということである.

\section{（5）実験を再現するためのパラメータ調整}

ここまでに示したように，球形要素と非球形要素のど ちらの解析結果も, 実験結果を十分に再現寸るには至ら なかった. そこで, 解析パラメータを調整して再現精度
の向上を試みた. 解析で衝撃荷重を十分な精度で再現で きない理由は、実際の粒子の形状や粒度分布を完全に再 現できないことに起因していると考えられる。現時点で は、実際の粒子の形状及び粒度分布を理論的に近似する 方法がないため，試行錯誤で再現を試みた。この検討は， 工学的には意味のあるものではないが，この検討結果が 本研究の結論に重要な意味を持つため, 試行錯誤ではあ るものの, その結果を示す.

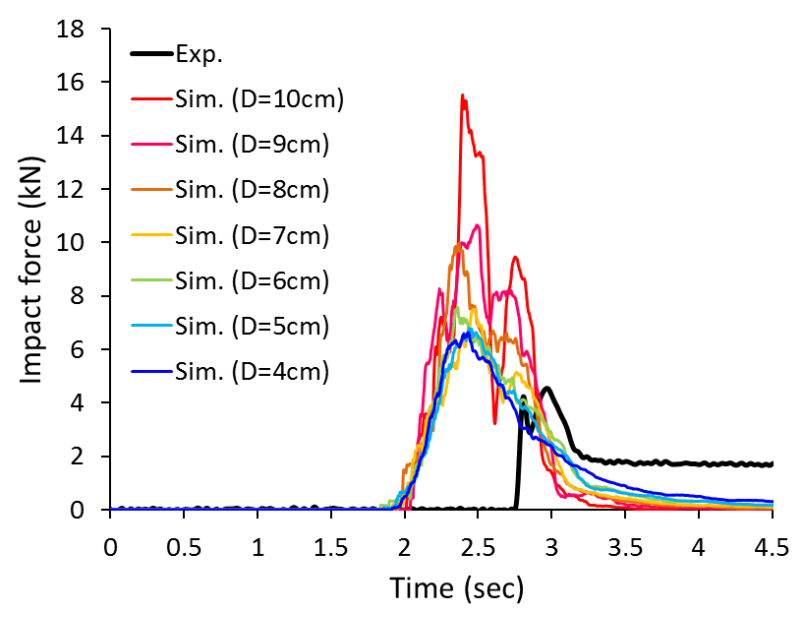

図-13 衝撃力の時刻歴（球形要素）

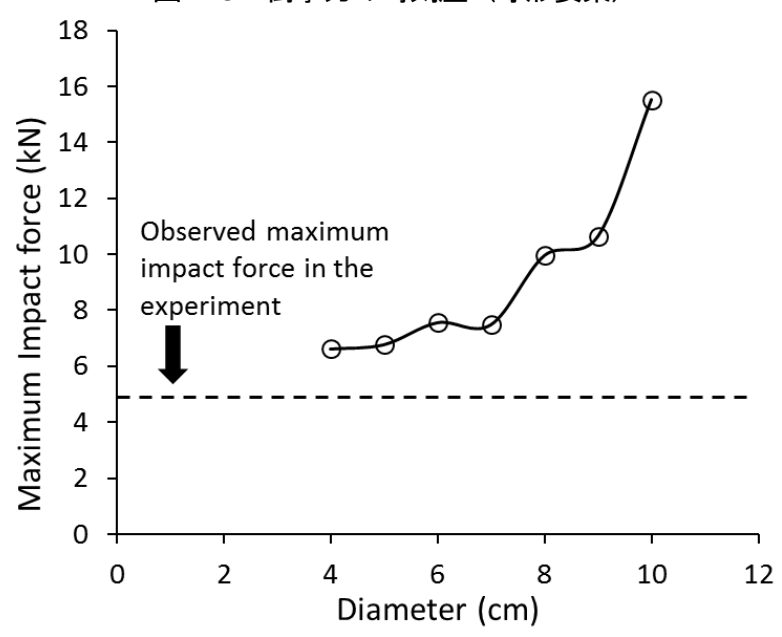

図一14 最大衝撃力と要素サイズの関係（球形要素）

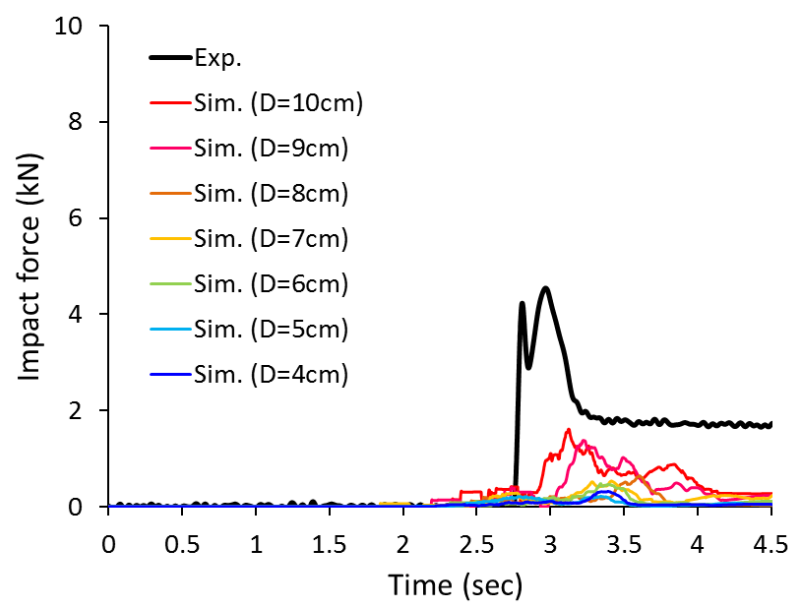

図-15 衝撃力の時刻歴 (直線形要素) 
特に，非球形要素を用いた場合に，流動挙動に大きな 影響を与えると思われる底面摩擦角を調整して，実験の 再現を試みた。この検討には，直線形要素を用いた。底 面摩擦角を変化させて複数ケースの解析を行ったところ, 底面摩擦角が 17 度の条件で実験結果とのよい対応が確 認された．流動の様子（直径 $4 \mathrm{~cm}$ のケース）を図-19に, 衝撃力の時刻歴を図-20に，最大衝撃力と要素サイズの 関係を図-21 に示す. 流動挙動, 堆積状況, 衝撃力のい ずれも実験結果と概ね一致している，特に要素サイズが 小さいケースでは実験結果との良い一致が確認できる. この結果に関して重要なことは, 非球形要素を用いて適 切なパラメータを設定することができれば，実現象を精 度よく予測することができるということである．先述の ように, 本研究で考慮した要素サイズは $4 \mathrm{~cm}$ が最小で あり，この要素サイズは実際の砕石の最大粒径に近いも のであり，当然ながら実際の粒径そのものを表現してい るわけではない. しかしながら，ここで示した結果のよ うに，ある一定の要素サイズ以下の条件で適切なパラメ 一タを設定すれば，実際の粒径を直接的に表現しなくて も，実現象に近い衝撃力を評価できると言える。なお， 球形要素についても, 同様に底面摩擦角の調整を行った が，球形要素の場合は大きな変化が見られなかった。 そ の例として, 図-22 に直径 $4 \mathrm{~cm}$ の球形要素で 17 度と $22^{\circ}$ の 2 種類の底面摩擦角を用いた場合の衝撃力の時刻 歴を示す，先にも言及したが，球形要素は回転すること で摩擦を低減するため, 底面摩擦角を多少変化させても 解析結果に大きな影響がないためにこのような結果が得 られると考えられる。つまり，球形要素を用いた場合は， パラメータ調整をしたとしても実現象を高精度に表現す ることは難しく, 衝撃力を過大評価すると結論付けられ る.

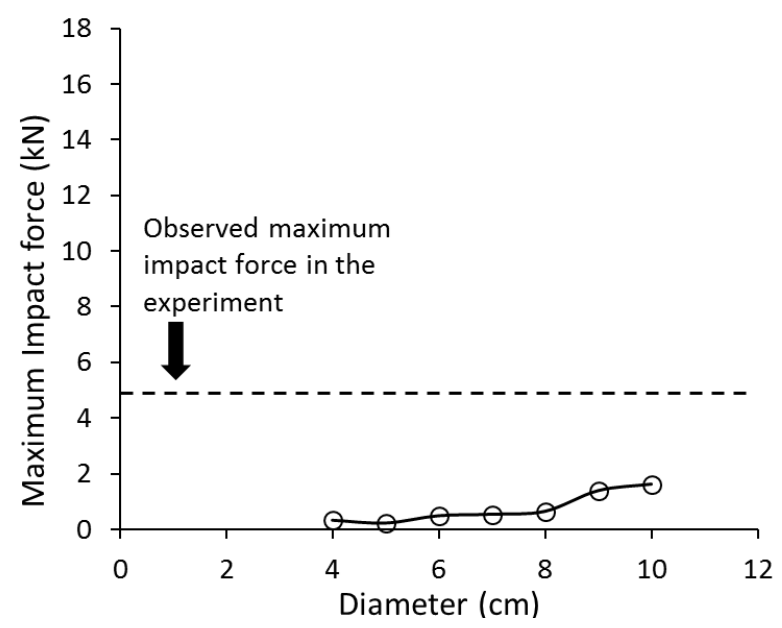

図ー16 最大衝撃力と要素サイズの関係（直線形要素）

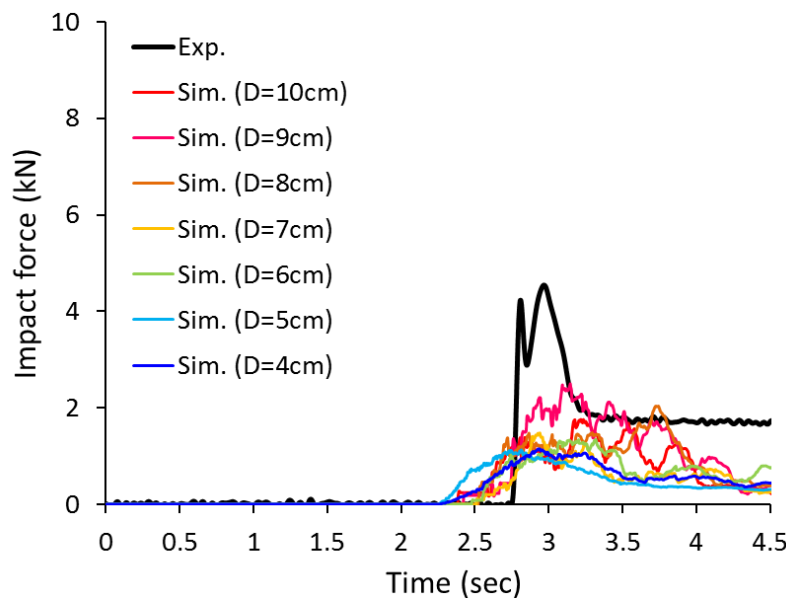

図-17 衝撃力の時刻歴 (テトラ形要素)

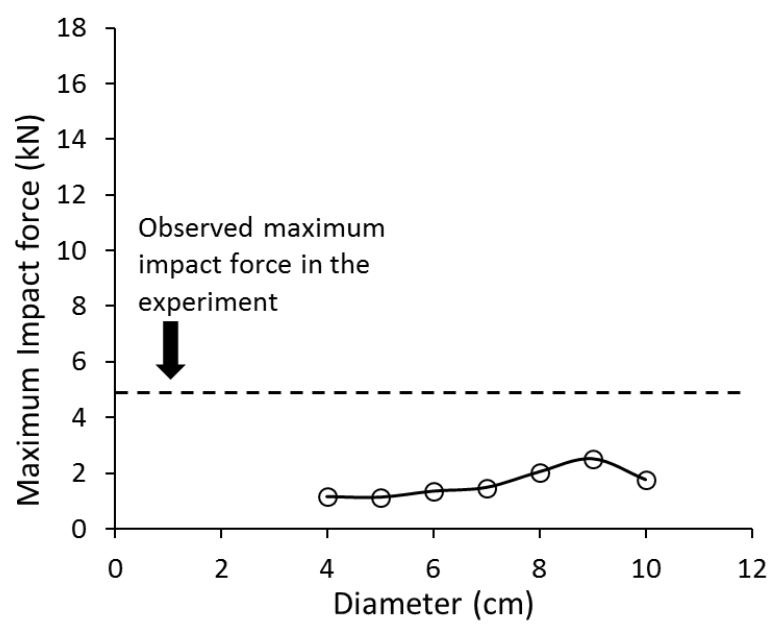

図－18 最大衝撃力と要素サイズの関係（テトラ形要素）

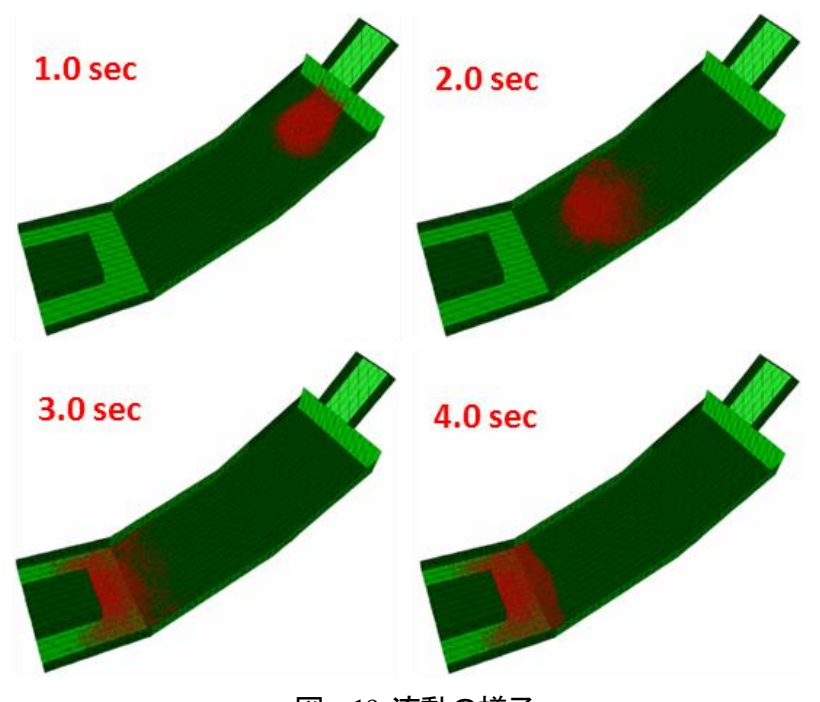

図一19 流動の様子

(解析結果, 直線形要素 $4 \mathrm{~cm}$, 底面摩擦角17度) 


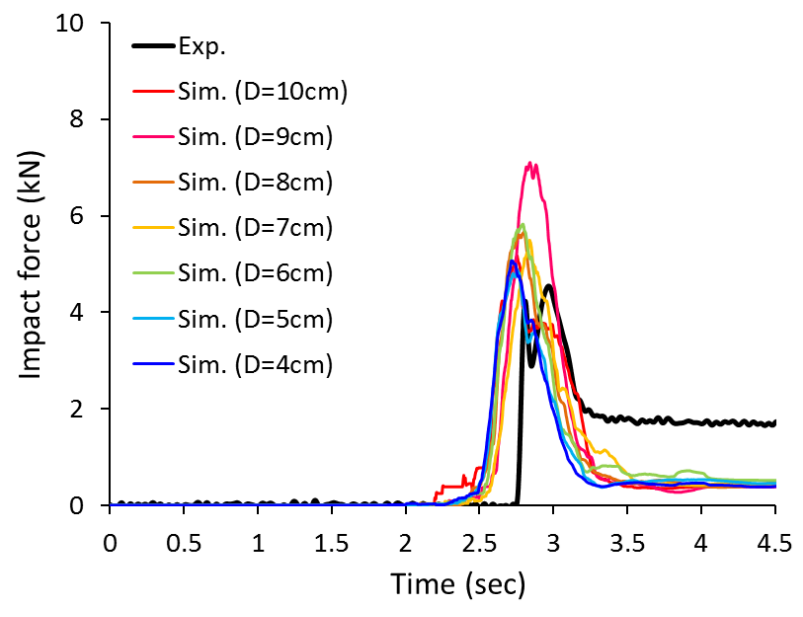

図-20 衝撃力の時刻歴（直線形要素, 底面摩擦角 17 度）

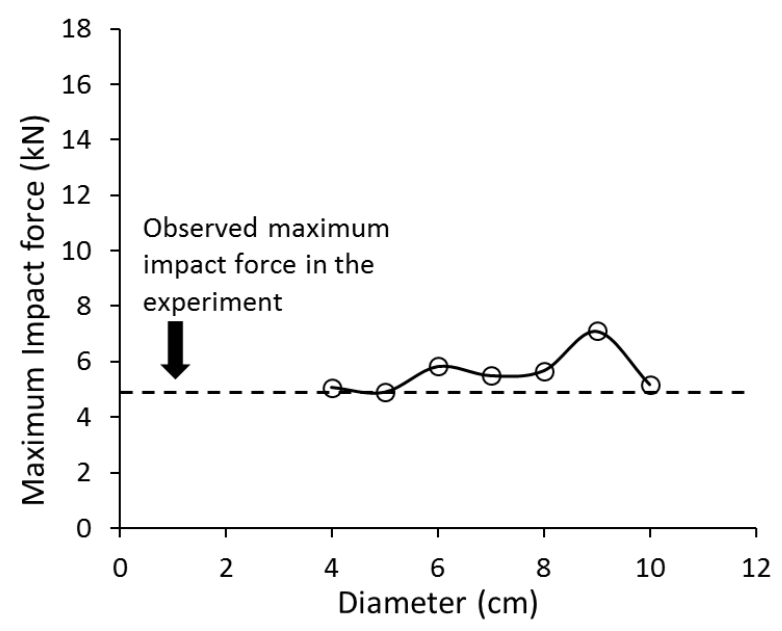

図-21 最大衝撃力と要素サイズの関係

(解析結果, 直線形要素, 底面摩擦角17度)

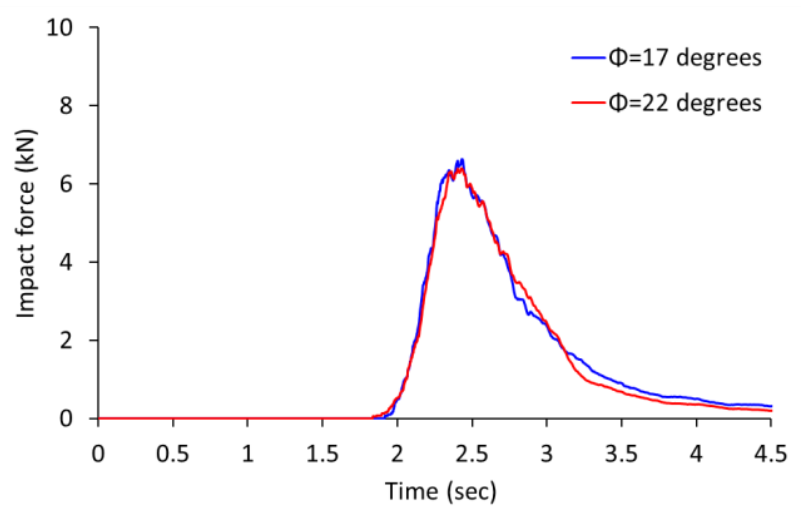

図一22 底面摩擦角の影響（球形要素 $4 \mathrm{~cm}$ ）

\section{4. 工学的利用のための留意点の整理}

本研究で得られた知見に基づいて，DEMを用いて土 砂の衝撃力評価に適用する際の留意点について整理する. 先述のように, 衝撃力が収束する要素サイズが存在し, その条件を守らない限り適切な評価は行えない. そのた
め, 要素サイズは解析結果を支配する重要な検討項目と して挙げられる.この検討を事前に行うことを前提とし て，要素形状について言及する.

非球形要素を用いる場合, 適切なパラメータ設定が可 能であるならば，実現象を高精度に表現できる可能性が ある．ただし，これを達成するためには，パラメータを 検討するための十分な判断材料があること，および，感 度分析などを実施してパラメータが解析結果に及ぼす影 響を十分に把握できることが求められる．特に，粒子間 摩擦角や粒子と斜面底面の摩擦角の值は流動挙動に大き な影響を与えるため, 十分な情報と感度分析が必要と考 えられる.

これに対して，球形要素を用いた場合は，実現象を精 度よく表現することは難しく，実際の衝撃力を過大評価 することになる．ただし，本研究で得られた結果の範囲 内では，実験の最大衝撃力に対して1.5倍程度の值を示 しており，工学的な観点から考えれば，この評価結果は 必ずしも精度が悪いものとして切り捨てるべきではない と考えられる.つまり, 球形要素を用いる場合には, 衝 撃力が過大評価となることを理解した上で, 安全側の評 価結果として考えれば，防護工の設計や構造物に作用寸 る衝撃力の評価のためには利用価值があると思われる.

序論で記載したように，現状の実務レベルの評価手法は 失点系の考え方に基づくものであり，衝撃力の時間変化 や空間的な分散機構および地形の影響などの評価が難し い. DEMによる解析では粒子群としての流動特性を直 接的に表現するため, 球形要素を用いた解析であっても これらの検討に対して有益な情報が得られる．そのため， 球形要素であっても従来手法に比べれば高度な検討が可 能であり，工学的利用の中で衝撃力の概略的な值を得る という目的に対しては利用可能と考えられえる. また, 球形要素を用いる利点として, 図-8,9および図-22に示し たように，入力パラメータの感度が鈍いという点も挙げ られる.この事実は，粒状体としての流動特性の表現精 度が低いというというデメリットである一方で，工学的 利用を考える上では解析条件の設定が容易になるという 利点であると思われる，つまり，パラメータを決定する ための判断材料がどうしても揃わないような条件下では, 無理に非球形要素を用いるよりも，一般的なパラメータ の值で球形要素を用いる方が工学的に意味のある評価結 果を得ることができる場面もあると考える，ただし，こ こでの議論は，衝撃力の評価に限定したものであり，到 達範囲などの評価にそのまま適用できるものではないこ とを言及しておく.

ここまでに整理した知見をもとに，DEMを土砂の衝 撃力評価に適用する際の手順と考え方を提案する. 図一 23に提案する評価フローを示す．まず，最も重要な支配 要因である要素サイズの検討が必要となる。この検討に 
おいて, 衝撃力が収束する要素サイズを把握する.その 上で，パラメータ決定のために十分な情報が整備されて いるかどうかを判断する．つまり，各パラメータを推定 できる実験データなどが整備されている必要がある．特 に非球形要素を用いた解析の中で感度の高いパラメータ である摩擦角について情報が整備されている必要がある。 パラメータ決定に対して十分な情報が整備できない場合 には，球形要素を用いることを検討する．ただし，この 場合は必ず過大評価となることに留意し, 衝撃力の值の 概略值を求めるという目的の本で評価結果を利用すべき である. パラメータ決定に対して十分な情報があると判 断される場合には，非球形要素を用いて高精度な評価結 果を追求する. ただし, 入力パラメータの変化に対して 解析結果が大きく変化する可能性があるため, その点に 留意して解析を実施する必要がある，最後に，パラメー タの感度分析と従来手法による結果との比較検討を行う ことで，評価結果の妥当性を確認する.

ここに示した評価フローは，現段階では十分なもので はないが，今後のDEMの工学的利用を考える上で議論 の一助にはなると考える.

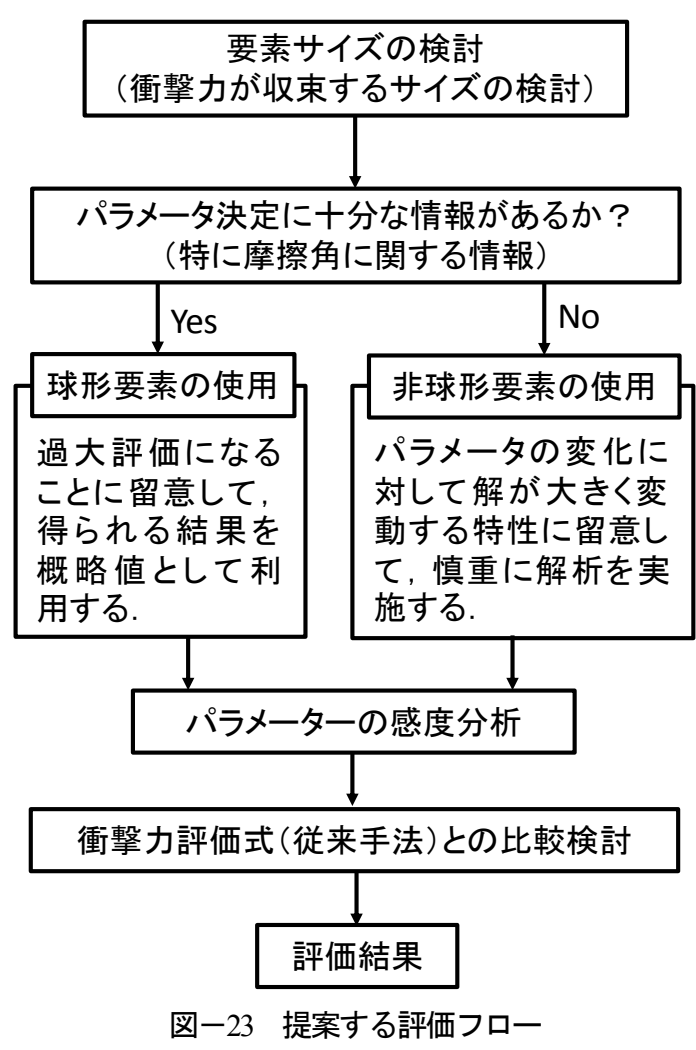

\section{5. 結論}

本研究では，砕石を用いた実大規模実験を再現するこ とにより，DEM を用いた土砂の衝撃力評価のための計 算条件について，下記の知見を得た。
(1) 衝撃力が収束する要素サイズが存在する.この解 が実現象と必ずしも一致するわけでないが，要素 サイズに依存しない解を得るという意味で工学的 利用を考える上で極めて重要である. そのため, 要素サイズの検討は最も重要な検討項目として考 えられる。

(2) 球形要素を用いた場合，実現象を精度よく予測す ることは難しいが，衝撃力が過大評価になること を理解した上で評価結果を用いるのであれば，工 学的観点から利用価值がある. 現状の実務レベル で用いられる評価式では評価の難しい衝撃力の時 間変化や空間的な分散機構および地形の影響など の評価が可能であり, 衝撃力の概略的な值を求め るというレベルでは工学的に有益な情報を得るこ とができる．また，解析パラメータの感度が鈍い ため，パラメータ決定のための情報が不足してい る条件下では, 非球形要素よりもパラメータを決 定しやすいということもメリットの 1 つである.

(3) 非球形要素を用いた場合, 適切なパラメータを設 定することができれば，実現象を高精度に予測す ることができる．特に，粒子と斜面底面の間の摩 擦角（底面摩擦角）の值は流動挙動に大きな影響 を与えるため，慎重に検討する必要がある．また， 解析パラメータの変化が解析結果に与える影響が 大きいため, 感度分析などにより結果の妥当性の 検証が必要となる.

上記の知見に基づいて，評価フローを提案した。本研 究では，粒度分布や水の影響を検討対象外としたため, 上記の結論は土砂流動という現象に対して完全に普遍性 のあるものではなく，あくまで限定的な条件の中で成立 するものである.ただし, 力学現象を左右する要因の影 響や球形要素と非球形要素の使い道など，DEM を土砂 の衝撃力評価に適用する上で留意すべき工学的条件の整 理のための情報を蓄積することができた。

謝辞 : 本研究の実施に際し，原子力規制庁より貴重な実 験データを提供頂いた。 また, 本研究の一部は科学研究 費補助金・基盤研究（S）課題番号 26220002「ものづく り HPC アプリケーションのエクサスケールへの進化」 から支援を頂いた。記して謝意を表す。

\section{参考文献}

1) 仲野公章, 右近則男, 砂質崩土の衝撃力に関する実験, 砂防学会誌, Vol.39, No.1,pp.17-23, 1986.

2) 中堤治朗, 谷敬, 崩落土の衝撃力に関する実験的研究, 土木学会論文報告集, No.325,pp.119-127, 1982.

3) 阿部慶太, 中島進, 渡辺健治, 獅子目修一, 雪岡剛 哲, 中瀬仁, 中村英孝, 中村晋, 大型斜面による岩塊 転動と土砂流動の挙動および衝撃荷重特性に関する 検討, 第 59 回地盤工学シンポジウム平成 26 年度論文 
集, pp.155-162, 2014

4) 森脇寛, 崩土の到達距離予測, 地すべり, Vol.24, No.2, pp.10-16, 1987.

5) 大久保駿, 吉松弘行, 綱木亮介, 資料解析によるがけ崩 れの崩土の到達距離の予測, 地すべり, Vol.32, No.2, pp.26-31, 1995.

6) 楠本岳志, 中瀬有祐, 藤本睦, 中井真司, 統計的手法を用 いた事例解析による地すべり到達距離の検討, 日本地 すべり学会誌, Vol.43, No.1, pp.1-8, 2006.

7) O. Hunger, A model for the runout analysis of rapid flow slides, debris flows and avalanches, Canadian Geotechnical Journal, Vol.32, No.4, pp.610-623, 1995.

8) 国土交通省, 土砂災害警戒区域等における土砂災害防 止対策の推進に関する法律施行令第 2 条第 2 号の規 定に基づき国土交通大臣が定める方法等を定める告 示（国土交通省告示第三百三十二号）,2001.

9) 芦田和男, 江頭進治, 佐々木浩, 斜面崩壊の発生機構と 土石流の流動機構,京都大学防災研究所年報, 第 30 号, B-2, pp.507-526, 1987.

10)Denlinger, R. P. and Iverson, R. M. : Flow of variably fluidized granular masses across three-dimensional terrain: 2. Numerical predictions and experimental tests, Journal of Geophysical Research, 106, B1, pp.553-566, 2001.

11)S. Moriguchi, R. I. Borja, A. Yashima, K. Sawada, Estimating the impact force generated by granular flow on a rigid obstruction, Acta Geotechnica, Vol.4, pp.57-71.

12)S. Moriguchi, A. Yashima, K. Sawada, R. Uzuoka and M. Ito, Numerical simulation of flow failure of Geomaterials based on fluid dynamics, Soils and Foundations,45(2), pp.155-166, 2005.

13)沢田和秀, 野々山栄人, 八嶋厚, 森口周二: 斜面崩壊土砂 の挙動予測解析一の SPH 法の適用, 混相流, 22(4), pp.339-347, 2008.

14)阿部慶太, Johansson Jorgen, 小長井一男: MPMを応用し た拘束長距離土砂流動の運動範囲予測のための数値 解析手法,士木学会論文集 C, Vol.63, No.1,pp.93-109, 2007.

15)A. P. Cundall, A Computer model for simulating progressive,
Large Scale movement in blocky rock system, Proceedings of ISRM Symposium, pp.11-18, 1971.

16)G. H. Shi and R. E. Goodman., Discontinuous deformation analysis: A new method for computing stress strain and sliding of blocks systems, Proceedings of the 29th U.S. Symposium on Rock Mechanics, pp. 381-393, 1988.

17)若井明彦, 鵜飼恵三, 清水義彦, 長田健吾, がけ崩れによ る土砂到達範囲の DEM シミュレーションと簡易予測 法の提案, 日本地すべり学会誌, Vol.40, No.5, 157, pp.366376, 2004.

18)Paul W. C.: DEM prediction of industrial and geophysical particle flows, Particuology, 8, pp.106-118, 2010.

19)Teufelsbauer H., WangY., Pudasaini S. P., Borja R. I., Wu W.: DEM simulation of impact force exerted by granular flow on rigid structures, Acta Geotechnica, 6, pp.119-133, 2011.

20)Chiao-Yin Lu, Chao-Lung Tanga, Yu-Chang Chanb, Jyr-Ching Hua, Chung-Chi Chic: Engineering Geology, Forecasting landslide hazard by the 3D discrete element method: A case study of the unstable slope in the Lushan hot spring district, central Taiwan, Vol. 183, pp.14-30, 2014.

21)Osher, S., Sethian, J. A., Fronts propagating with curvaturedependent speed: Algorithms based on Hamilton-Jacobi formulations, J. Comput. Phys., 79, pp.12-49,1988

22) Sussmann, M., P. Smereka and S. Osher: A level set approach for computing solutions to incompressible two phase flow, J. Comp. Phys, Vol. 114, pp.146-159, 1994.

23) Lim K. W., Kawamoto R., Andrade J. E., Grain-scale discrete analysis methods for real granular matter: Granular element and coupled Level Set-Discrete Element Methods, Geomechanics from Micro to Macro, Proceedings of IS-Cambridge 2014, pp. 55-60, 2014.

24) 地盤工学会 : 地盤に関寸る解析技術（個別要素法) 講習会資料, pp.58-69, 2015.

\section{A SIMULATION OF LARGE SCALE SEDIMENT FLOW EXPERIMENT USING DEM}

Shuji MORIGUCHI, Yuma OHTA, Shinsuke TAKASE, Kenjiro TERADA, Keita ABE and Takayuki AOKI

In order to study suitable calculation conditions for estimating impact force of sediment flow using DEM, a simulation of a large scale sediment flow experiment was performed. By changing element size and element shape, the effects of thease factors were investigated in the simulation. Based on the obtained results, importance of element size and flow chracteristics of the spherical ekement and non-sherical eklement are analyzed. In addition, a flow of the estimation process is proposed, and some points of attention are summarized from the view points of engineering. 